\title{
THE FIRST WORD
}

\section{SEPTEMBER IS THE CRUELEST MONTH}

Big Sur, Bangor, Wilkes Barre, Harper's Ferry; Saint Paul, Glens Falls, San Francisco, Old El Paso; [chorus] I've been everywhere, man; I've been everywhere.

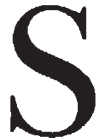
uch, with variations, was the song of the American hobo during the Great Depression: a litany of place names recited to railroad rhythms. The hobo, we're told, was not strictly a vagrant, but a "hoe boy," a footloose laborer plying his tools where both the harvest and the times were good. In that itinerant spirit-as well as in our own version of a great depression-we contemplated the first weeks of September:

Boston, Washington, Edinburgh, Williamsburg;

Milan, München, Cinnaminson, Arlington;

I should be everywhere, man; I should be everywhere.

The biotech version doesn't scan even as well as its ironhorse ancestor. Perhaps that's the fault of the Boeing 747 ; there is no perceptible rhythm to air travel, just wait and shuffle and wait and shuffle. Wait for the plane; shuffle on. Wait to land; shuffle off. Wait for baggage; shuffle into a cab. To Boston for the Nature conference on the molecular biology of cancer. To Washington, D.C., for Biotech 84. And, had we world enough and time, to Munich for the Third European Congress on Biotechnology; to Rensselaerville, NY, for a conference on DNA and RNA probes; to Cold Spring Harbor, NY, for vaccines; to Knoxville, TN, for tissue-culture of higher plants. Williamsburg, VA, for "Immunity to Cancer." Washington again for more on cancer research. Paris for the Seventh European Meeting on Genetic Transformation. St. Lucia, Queensland, for "Fermentation Technology."

These are just a few of the places it would have been nice to be: some score of meetings, most of them public, on three continents. Alas, most of the meeting planners had the foresight to sandwich their gatherings in between North America's Labor Day at the beginning of the month and the Jewish New Year at the end: twenty-odd meetings in as many days. Eliot was wrong. September, not April, is the cruelest month.

Ralph Waldo Emerson wrote that "...the wise man stays at home," and we are now tempted to agree. But, Emerson continued, "...when his necessities, his duties, on any occasion call him from his house, or into foreign lands, he is at home still and shall make men sensible by the expression of his countenance that he goes the missionary of wisdom and virtue..." The proponent of self-reliance was attacking the Nineteenth Century American habit of looking abroad for all wisdom and knowledge, but we rather think he was cutting off his nose to spite his face. What vessel of knowledge is so full that it can only pour out and need not be filled? Better to travel as a pilgrim than as a missionary.

Professional conferences and trade exhibitions are exhausting. Delegates, exhibitors, and journalists complain constantly. Conferees sift wearyingly through mounds of apparent chaff to find the few grains of data they want. Exhibitors lie in ambush in their booths, hoping someone with authority to buy will hesitate as he passes. When conference sessions are in full cry and the exhibitions are quiet, the exhibitors prowl the aisles, hoping to sell to one another.

Yet despite the dispraise, we go lemming-like to meetings, and the meetings proliferate. London Online will probably continue to expand its schedule of Biotech conferences in Europe, the U.S., Singapore, and beyond. A prominent Boston publisher of trade magazines and mounter of trade shows had a salesman of its own in the aisles at Biotech 84 in Washington, hawking space for a new trade exposition. Nature Publishing Company itself will probably add a $\mathrm{BIO} / \mathrm{TECHNOLOGY}$ conference.

Can the field handle so many gatherings? Will biotechnologists tolerate so much travel?

In the long run, probably not. One might as well ask, Can the field handle so many biotechnology companies?

Biotechnology can, however, easily handle a reasonable number of top-flight exhibitions. Indeed, the field must have them. Organizers will continute to offer conferences as long as there is enough interest to make them profitable. Ultimately, the conferees decide which meetings will live and which will die.

Rather than cut-and-dried panels and reluctant question-and-answer sessions, we would like to see carefully structured sessions that bring intelligent professionals together with the very best in their field for serious exchanges. We would like to see discussions that encourage participants to share their own views, to risk embarrassment. We would like to see exhibitions that provide a solid foundation for commercial dealing, matching people with a need and people with a solution.

Ultimately, perhaps, serendipity is the best justification for business travel: the word itself is born of travel and chance discovery of new lands. For advice to the moderns, perhaps we should look past Emerson to Francis Bacon, who advised travelers at the dawn of the Seventeenth Century, that "The things which are to be seen and observed are... whatsoever is most memorable in the places where they go.... As for triumphs, masks, feasts, weddings, funerals, capital executions [i.e., the contemporary analogues of trade exhibitions], and such shows, men need not be put in mind of them; yet they are not to be neglected... Let him also see and visit eminent persons in all kinds, which are of great name; that he may be able to tell how the life agreeth with the fame.... When a traveler return home, let him not leave the countries where he hath traveled altogether behind him; but maintain a correspondence by letters with those of his acquaintance which are of most worth."

This last, the personal contact, will probably be the most valuable legacy of the enervating rounds of travel that stretch ahead of us. With a bit of luck, biotechnology will soon outgrow much of its feeling of community. The field will lose much in its transition from town to city, even as it gains in vitality and power.

The harried and jet-lagged will continue to malign the industry's circuses. But the contacts we make there will, if tended, endure and flourish. And, as we grow with the field, we will flourish with those we know.

And that's why we will continue to wait and shuffle, wait and shuffle.
-Douglas McCormick 